\title{
Impact of Low Concentration Factor Microfiltration on the Composition and Aging of Cheddar Cheese ${ }^{1}$
}

\author{
M. Neocleous, D. M. Barbano, and M. A. Rudan² \\ Northeast Dairy Foods Research Center \\ Department of Food Science, \\ Cornell University, Ithaca, NY 14853
}

\section{ABSTRACT}

The effect of microfiltration (MF) on proteolysis, hardness, and flavor of Cheddar cheese during 6 mo of aging was determined. Raw skim milk was microfiltered twofold in two cheese making trials. In trial 1, four vats of cheese were made in $1 \mathrm{~d}$ using unconcentrated milk (1X), 1.26X, 1.51X, and 1.82X concentration factors (CF). Casein-(CN)-to-fat ratio was constant among treatments. Proteolysis during cheese aging decreased with increasing $\mathrm{CF}$ due to either limitation of substrate availability for chymosin due to low moisture in the nonfat substance (MNFS), inhibition of chymosin activity by high molecular weight milk serum proteins, such as $\alpha_{2}$-macroglobulin, retained in the cheese or low residual chymosin in the cheese. Hardness of fresh cheese increased, and cheese flavor intensity decreased with increasing CF. In trial 2, the $1 \mathrm{X}$ and $1.8 \mathrm{X} \mathrm{CF}$ were compared directly. Changes made in the cheese making procedure for the 1.8X CF (more chymosin and less cooking) increased the MNFS and made proteolysis during aging more comparable for the $1 \mathrm{X}$ and $1.8 \mathrm{X}$ cheeses. The significant difference in cheese hardness due to $\mathrm{CF}$ in trial 1 was eliminated in trial 2 . In a triangle test, panelists could not differentiate between the $1 \mathrm{X}$ and $1.8 \mathrm{X}$ cheeses. Therefore, increasing chymosin and making the composition of the two cheeses more similar allowed production of aged Cheddar cheese from milk concentrated up to $1.8 \mathrm{X}$ by MF that was not perceived as different from aged Cheddar cheese produced without MF.

(Key words: Cheddar cheese, microfiltration, concentration factor, proteolysis)

Received June 11, 2001.

Accepted March 22, 2002.

Corresponding author: David M. Barbano; e-mail: dmb37@ cornell.edu.

${ }^{1}$ Use of names, names of ingredients, and identification of specific models of equipment is for scientific clarity and does not constitute any endorsement of product by authors, Cornell University, or the Northeast Dairy Foods Research Center.

${ }^{2}$ International Food Network, Ltd., The Science and Technology Center, University of Reading, Early Gate, Whiteknights Road, Reading, RG6 6BZ, UK.

\begin{abstract}
Abbreviation key: $\mathbf{C F}=$ concentration factor, $\mathbf{F D B}=$ fat on a dry basis, HCF = high concentration factor, $\mathbf{L C F}=$ low concentration factor, $\mathbf{M C F}=$ medium concentration factor, $\mathbf{M F}=$ microfiltration, $\mathbf{M N F S}=$ moisture in the nonfat substance, $\mathbf{S M}=$ standardized milk, $\mathbf{S N}=$ soluble nitrogen, $\mathbf{T N}=$ total nitrogen .
\end{abstract}

\section{INTRODUCTION}

Three approaches can be used for UF of milk prior to cheese making: low concentration factor (LCF) UF, medium concentration factor (MCF) UF, and high concentration factor (HCF) UF. Commercial Cheddar cheese (Garrett, 1987) and Mozzarella cheese (Swientek, 1984) produced by MCF UF milk were unsuccessful in the US because texture and flavor did not meet commercial standards. Cheese flavor and texture development were also reported to be slower in MCF UF Cheddar cheeses made in research studies (Green et al., 1981, Creamer et al., 1987). Cheese composition is changed when MCF UF concentrate is used to make Cheddar cheese, and this has an impact on cheese texture and proteolysis during aging.

Milk serum proteins, such as $\alpha$-lactalbumin and $\beta$ lactoglobulin, are concentrated in the UF retentate and are retained in the water phase of the cheese. Maximum retention of whey proteins results in ca. $20 \%$ of the cheese protein content being whey protein when using HCF UF. The presence of whey proteins in cheese may reduce the rate of proteolysis during cheese aging due to an inhibition of chymosin activity (Creamer et al., 1987). Other high molecular weight milk serum proteins, such as immunoglobulins, are concentrated in UF retentate and are retained at a higher concentration in MCF UF cheese. These high molecular weight milk serum proteins may also inhibit the proteolytic activity of chymosin (Lelievre et al., 1990) during cheese aging.

Microfiltration (MF) processing of skim milk prior to cheese making using $0.1 \mu \mathrm{m}$ ceramic membranes (Neocleous et al., 2002) allows water, lactose, $\alpha$-lactalbumin and $\beta$-lactoglobulin, soluble minerals, and NPN to pass through the membrane in the permeate. Casein, however, does not pass through the membrane (St-Gel- 
ais et al., 1995; Jost et al., 1999). A skim milk MF retentate can be mixed with cream to produce milk for cheese making. In the case of MF, no increase in $\alpha$ lactalbumin and $\beta$-lactoglobulin concentration in the cheese is expected and no increase in cheese yield efficiency was observed (Neocleous et al., 2002). Thus, when Cheddar cheese is made from MF retentate, one might expect that negative impacts on texture (e.g., excessive firmness) and proteolysis (e.g., slower proteolysis) caused by UF would not occur.

Only one study (St-Gelais et al., 1995) on Cheddar cheese made from MF milk has been published. The milks used were the control (unconcentrated) milk and milks of concentration factor (CF) $1.22 \mathrm{X}, 1.43 \mathrm{X}$, and 1.66X. All milks were standardized to a constant crude CP-to-fat ratio. St-Gelais et al. (1995) reported that as CF increased, cheese CP increased (25.6 to 27.5\%), while moisture, fat on a dry basis (FDB), and moisture in the nonfat substance (MNFS) of the cheese decreased from 35.8 to $34.6,52.3$ to 49.0 , and 53.7 to $50.9 \%$, respectively. St-Gelais et al. (1995) concluded that if they had standardized the milk to a constant $\mathrm{CN}$-to-fat ratio, instead of a $\mathrm{CP}$ to fat ratio, with increasing $\mathrm{MF} \mathrm{CF}$, the moisture, MNFS, and FDB of the cheese made from MF retentate would be more similar to the control. Calcium concentration was also significantly higher in the MF cheeses than in the control cheeses. Proteolysis, as measured by $\mathrm{pH} 4.5$ soluble nitrogen $(\mathbf{S N})$ and TCA $\mathrm{SN}$, increased significantly with age in all cheeses. Proteolysis, however, was slower in the MF cheeses than the control. St-Gelais et al. (1995) concluded that the slower proteolysis in the MF cheeses was due to either the lower MNFS, or to low residual rennet in the MF cheeses compared to the control cheese. Hardness was significantly higher in the MF cheeses than in the control. St-Gelais et al. (1995) concluded that this was due to higher protein concentration and slower proteolysis in the MF cheeses. However, St-Gelais et al. (1995) did not attempt to modify the milk standardization and cheese making procedure to determine if changes to the cheese making procedure could make MF cheese composition and aging characteristics similar to the control cheese.

The first objective of our study was to determine the effect of LCF MF on the proteolysis (i.e., SN fractions, degradation of $\alpha_{\mathrm{s}}$ and $\beta$-CN) and hardness during 6 mo of Cheddar cheese aging when milk was standardized to a constant $\mathrm{CN}$-to-fat ratio (trial 1 ). The second objective was to develop modifications of the standard Cheddar cheese making procedure to minimize composition, proteolysis, texture, and sensory differences between cheese made from unconcentrated milk and cheese made from MF concentrate (trial 2).
Table 1. Comparison of cheese-making conditions for trials 1 and 2.

\begin{tabular}{|c|c|c|c|c|}
\hline \multirow[b]{3}{*}{ Parameter } & \multicolumn{4}{|c|}{ Concentration factor } \\
\hline & \multicolumn{2}{|c|}{ Trial 1} & \multicolumn{2}{|c|}{ Trial 2} \\
\hline & $1.0 \mathrm{X}$ & $1.82 \mathrm{X}$ & $1.0 \mathrm{X}$ & $1.8 \mathrm{X}$ \\
\hline $\begin{array}{l}\text { Amount of rennet } \\
(\% \text { of } 1.0 \mathrm{X})\end{array}$ & 100 & 33 & 100 & 48 \\
\hline $\begin{array}{l}\text { Temperature }\left({ }^{\circ} \mathrm{C}\right) \text { at } \\
\text { starter/rennet addition }\end{array}$ & 310 & 31.0 & 31.0 & 33.5 \\
\hline Ripening time (min) & 45.0 & 45.0 & 45.0 & 24.7 \\
\hline $\mathrm{pH}$ at rennet addition & 6.61 & 6.62 & 6.59 & 6.59 \\
\hline Cooking time $(\mathrm{min})$ & 30.0 & 30.0 & 30.0 & 15.0 \\
\hline Whey draining $\mathrm{pH}$ & 6.40 & 6.40 & 6.40 & 6.40 \\
\hline Milling $\mathrm{pH}$ & 5.30 & 5.30 & 5.30 & 5.30 \\
\hline
\end{tabular}

\section{MATERIALS AND METHODS}

\section{Trial 1}

Milk processing and cheese manufacture. Raw skim milk and cream were obtained from the Cornell University dairy plant. On the day before cheese making, the skim milk was microfiltered, as described previously (Neocleous et al., 2002), and the next day, four vats of full-fat, milled-curd Cheddar cheese were manufactured (Neocleous et al., 2001). The four treatments were the control (1X), 1.26X, 1.51X, and 1.82X CF of the standardized milk (SM). Cheese making conditions used in trial 1 were kept constant across all CF (conditions for control and 1.82X cheeses only are shown in Table 1). The only factor that was different among CF was the amount of chymosin added to the SM. In the 1.26X, 1.51X, and 1.82X SM, the amount of chymosin added was 80,60 , and $33 \%$ of the amount added to the control SM (100\%), as described previously (Neocleous et al., 2002). The reduction in chymosin was based on the study by St.-Gelais et al. (1995), our estimates of the reduction in total volume of whey in the vat for each CF that would partition between the curd and the removed whey, and some preliminary coagulation trials done with $\mathrm{MF}$ retentates of different $\mathrm{CF}$. It was recognized that in the first cheese making trial these levels of chymosin addition at different CF would be estimates. The goal of reduction of the level chymosin addition with increasing $\mathrm{CF}$ was to retain the same amount of chymosin per unit weight of cheese for all four CF. During cheese making, titratable acidity of the SM and whey, as well as $\mathrm{pH}$ of the SM, whey, and cheese were determined (Neocleous et al. 2002). Cheese was aged at $6^{\circ} \mathrm{C}$ for $6 \mathrm{mo}$.

Cheese sampling and sample preparation. Cheeses were sampled at four ages: d 3, d 30, d 90, and d 180. A cross-sectional slice, $1 \mathrm{~cm}$ thick, was removed from the middle of the 18-kg block of cheese, cut into chunks of about $2 \mathrm{~cm} \times 2 \mathrm{~cm}$, and ground at low speed 
Table 2. Mean $(\mathrm{N}=4)$ cheese make-times $(\min )$ for trial 1 .

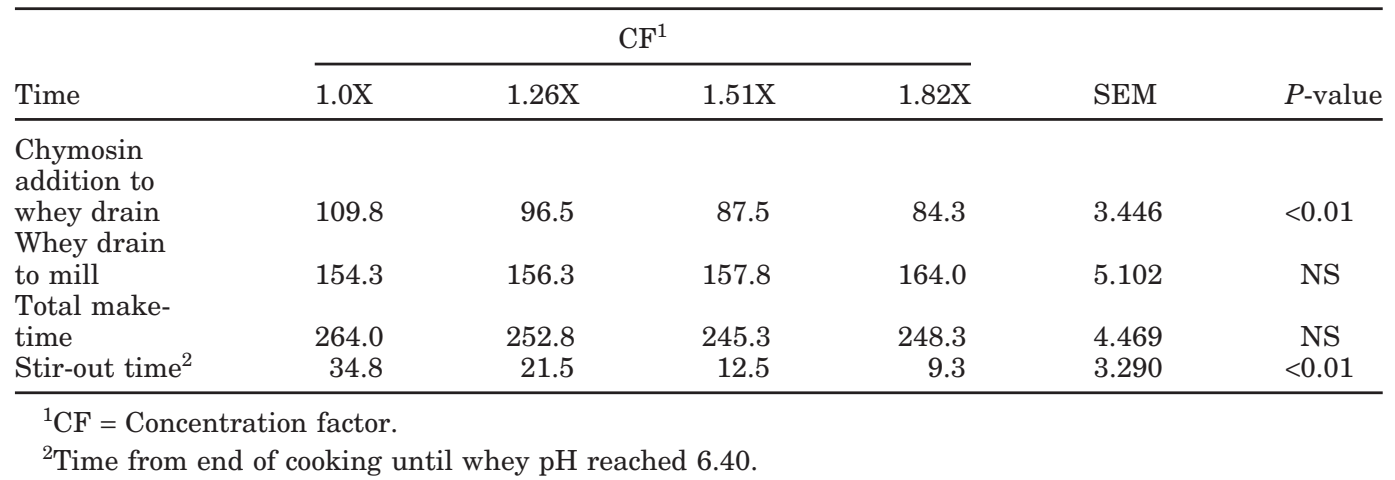

for about $5 \mathrm{~s}$ in a blender (Model 31BL92, Waring, New Hartford, CT) to a particle size of approximately 2 to 3 $\mathrm{mm}$. The ground cheese was mixed and packed with no headspace into plastic, 59-ml sample vials (Capitol Vial Corp., Fultonville, NY) and stored at $4^{\circ} \mathrm{C}$. The samples were extracted for soluble nitrogen determination or treated with SDS-PAGE sample buffer on the same day as the cheese was ground (i.e., d 3, 30, 90, and 180). All analyses were done on fresh cheese samples.

Cheese composition. Cheese moisture, fat, salt, calcium, $\mathrm{CP}$, and $\mathrm{pH}$ were determined as reported previously (Neocleous et al., 2002). Cheese $\mathrm{pH}$ and titratable acidity were determined in duplicate during aging (Lau et al., 1991).

Proteolysis. Both $\mathrm{pH} 4.6$ acetate buffer and $12 \%$ TCA SN (Bynum and Barbano, 1985) were used as indices of cheese proteolysis during aging. The sample weights used for the analysis were 0.75 and $1.5 \mathrm{~g}$ for the $\mathrm{pH}$ 4.6 SN and $12 \%$ TCA SN, respectively. Total nitrogen (TN) of each cheese at all ages was determined, and the average TN of each cheese was calculated at the end of the 180-d aging period. Both $\mathrm{pH} 4.6$ and $12 \%$ TCA SN were expressed as a percentage of the average TN for each cheese.

SDS PAGE was used to measure proteolysis of $\alpha_{\mathrm{s}}$ and $\beta$-CN during aging. The procedure was described previously (Verdi et al., 1987), except that a constant $15 \%$ acrylamide gel concentration was used. Cheese samples were prepared as follows: $1 \mathrm{~g}$ of cheese was mixed with $10 \mathrm{ml}$ of sample buffer and blended for 1 min using a homogenizer (Omni Mixer Homogenizer, Model 17105, Omni International, CT, USA) at the 3.5 setting (about $5000 \mathrm{rpm}$ ). Next, $0.1 \mathrm{ml}$ of the blended mixture was combined with $0.9 \mathrm{ml}$ of sample buffer containing dithiothreitol in a glass (3-ml) sample vial. All the prepared vials were placed in boiling water for 5 min, cooled to room temperature, and frozen $\left(-20^{\circ} \mathrm{C}\right)$ until use. On the day of running electrophoresis, the samples were thawed, boiled for $5 \mathrm{~min}$, and left to cool to room temperature before loading on the gel.
Six $\mu$ l of the d-3 cheese sample buffer mixtures and $7 \mu \mathrm{l}$ of the $\mathrm{d}-30,-90$, and -180 cheese sample buffer mixtures were loaded per slot for all CF. A raw milk qualitative reference sample was also loaded on each gel at a loading volume of $7 \mu \mathrm{l}$. The destained gels were scanned using a Model 620 (1-D analyst) video densitometer (BioRad Laboratories, Rockville Center, $\mathrm{NY}$ ) and equipped with a filter for $600 \mathrm{~nm}$ for the fluorescent white light source. Para- $\kappa-\mathrm{CN}$ was used as an internal standard, since it is not hydrolyzed during Cheddar cheese aging (Nath and Ledford, 1973). The ratio of the $\alpha_{\mathrm{s} 1^{-}}$plus $\alpha_{\mathrm{s} 2}-\mathrm{CN}\left(\alpha_{\mathrm{s}}-\mathrm{CN}\right)$ peak height and the $\beta$-CN peak height to the para- $\kappa$-CN peak height at each time of aging was calculated (Lau et al., 1991). The percentage degradation of $\alpha_{\mathrm{s}}-\mathrm{CN}$ was calculated by subtracting each of the ratios $\left(\alpha_{\mathrm{s}}-\mathrm{CN} /\right.$ para- $\left.\kappa-\mathrm{CN}\right)$ at $\mathrm{d} 30,90$, and 180 from the ratio $\left(\alpha_{\mathrm{s}}-\mathrm{CN} /\right.$ para- $\left.\kappa-\mathrm{CN}\right)$ at $\mathrm{d} 3$, dividing by the ratio $\left(\alpha_{\mathrm{s}}-\mathrm{CN} /\right.$ para- $\left.\kappa-\mathrm{CN}\right)$ at $\mathrm{d} 3$, and multiplying by 100 . The same procedure was followed for $\beta$-CN degradation.

Cheese hardness. Cheese hardness was measured using Texture Profile Analysis (Bourne, 1978) with an Instron Universal Testing Machine (Model TM, Instron Corp., Canton, MA). Five cheese cylinders, $2 \mathrm{~cm}$ high and $2 \mathrm{~cm}$ in diameter, were tested for each cheese at each age. The cheese cylinders were warmed from 4 to $10^{\circ} \mathrm{C}$ and tempered for $1 \mathrm{~h}$ prior to analysis. One- to 5$\mathrm{kg}$ weights were used for the calibration of the Instron. The crosshead speed used was $12.7 \mathrm{~cm} / \mathrm{min}$. Each of the five cheese cylinders (from the same cheese) was subjected to a $25 \%$ compression, and measurements were taken on first (hardness 1) and second (hardness 2) compression.

Experimental design and statistical analysis. Cheese was made on one day in each of four different weeks over a 5 -wk period. On each of the $4 \mathrm{~d}$ of cheese manufacture, four SM of four different CF (1X, 1.26X, $1.51 \mathrm{X}$, and 1.82X) were used to make Cheddar cheese. In the ANOVA model for cheese make times for trial 1 (Table 2), CF (i.e., treatment) was analyzed as a contin- 
Table 3. Mean squares, probabilities (in parenthesis), and $\mathrm{R}^{2}$ for titratable acidity, $\mathrm{pH}, \mathrm{pH} 4.6$, and $12 \%$ TCA soluble nitrogen (SN), $\alpha_{\mathrm{s}^{-}}$ and $\beta$-CN degradation, and hardness on first compression of Cheddar cheese during $180 \mathrm{~d}$ of storage at $6^{\circ} \mathrm{C}$ for trial 1 .

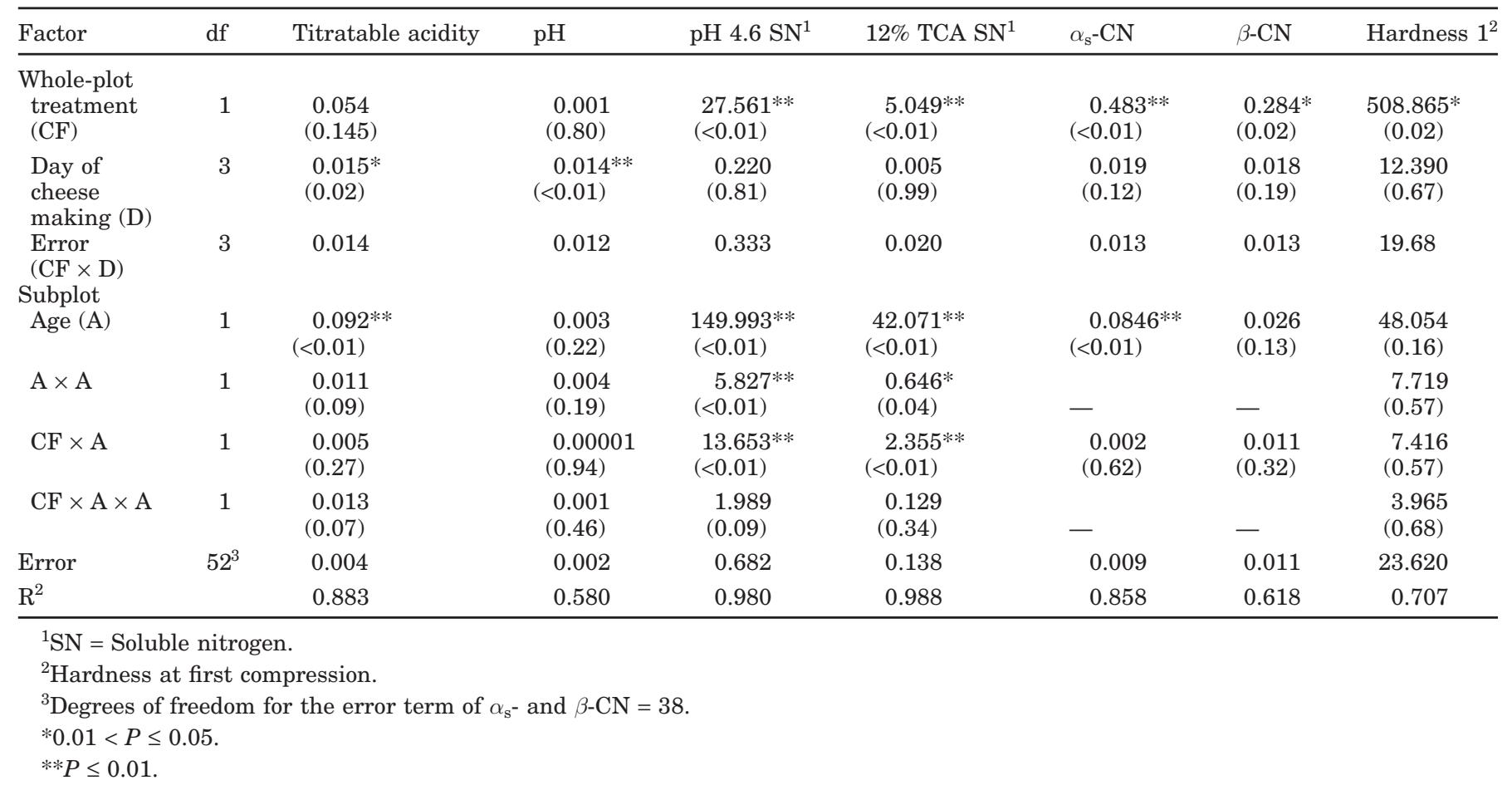

uous variable, while cheese making week (i.e., batch of milk) was blocked. The interaction term of $\mathrm{CF} \times$ cheese making week was used as the error term for treatment.

ANOVA for changes in cheese SN, titratable acidity, $\mathrm{pH}$, and hardness due to treatment and time of aging were done using a split-plot design (Table 3). For the whole plot factor, CF was analyzed as a continuous variable, while cheese making week (i.e., batch of milk) was blocked. For the subplot factor, age and the quadratic form of age (age $\times$ age) were analyzed as continuous variables. The interactions of $\mathrm{CF} \times$ age and $\mathrm{CF} \times$ age $\times$ age were also included in the model. The interaction term of $\mathrm{CF} \times$ cheese making week was used as the error term for treatment effect. For all analyses, age was transformed as follows: age $=\mathrm{d}$ of storage at $6^{\circ} \mathrm{C}-$ [(last testing $\mathrm{d}$ - first testing $\mathrm{d}) / 2$ ]. This transformation made the data set orthogonal with respect to age.

To determine if there was a significant effect of $\mathrm{CF}$ on the starting $\alpha_{\mathrm{s}^{-}}$and $\beta-\mathrm{CN}$ to para- $\kappa$ - $\mathrm{CN}$ ratio at $\mathrm{d} 3$, $\mathrm{CF}$ was treated as a continuous variable, cheese making week was blocked, and the interaction term of $\mathrm{CF} \times$ cheese making week was used as the error term for treatment. For the analysis of $\alpha_{\mathrm{s}}$ - and $\beta$-CN degradation during aging, the model used was the same as the model used for SN. The quadratic term of age and its interaction with $\mathrm{CF}$, however, were not included in the model because there were only three data points (d 30,90, and 180) for each treatment. The PROC GLM procedure of SAS ${ }^{\circledR}$ was used for all data analyses (SAS User's Guide, 1990).

\section{Trial 2}

Modifications of the cheese making procedure. Trial 2 was performed as a follow-up study to trial 1 , with the goal of eliminating the chemical composition (mainly moisture) and proteolysis differences among treatments due to MF that were observed in trial 1. Trial 2 was a direct comparison of control cheese (1X) and cheese made from the highest CF MF milk (1.8X).

Microfiltration processing, preparation of the SM, and cheese making were performed as described pre-

Table 4. Mean $(\mathrm{N}=3)$ cheese making times $(\min )$ for trial 2.

\begin{tabular}{lcccr}
\hline & \multicolumn{2}{c}{$\mathrm{CF}^{1}$} & & \\
\cline { 2 - 3 } Time & $1.0 \mathrm{X}$ & $1.8 \mathrm{X}$ & SEM & LSD \\
\hline Rennet addition to & & & & \\
whey drain & $109.3^{\mathrm{a}}$ & $96.0^{\mathrm{b}}$ & 1.179 & 7.2 \\
Whey drain to mill & $154.0^{\mathrm{b}}$ & $185.3^{\mathrm{a}}$ & 2.896 & 17.6 \\
Total make-time & $263.3^{\mathrm{b}}$ & $281.3^{\mathrm{a}}$ & 2.944 & 17.9 \\
Stir-out time $^{2}$ & 32.0 & 32.3 & 1.670 & NS \\
\hline
\end{tabular}

${ }^{\mathrm{a}, \mathrm{b}}$ Means $(\mathrm{n}=3)$ within the same row without a common superscript differ $(P<0.05)$. Rows with no superscripts indicate no differences $(P>0.05)$ between the means.

${ }^{1} \mathrm{CF}=$ Concentration factor.

${ }^{2}$ Time from end of cooking until whey $\mathrm{pH}$ reached 6.40 . 
viously (Neocleous et al., 2002). A comparison of the key differences between trials 1 and 2 cheese manufacturing conditions is presented in Table 1 . The modifications made in trial 2 cheese making were as follows: a) the amount of chymosin added to the $1.8 \mathrm{X}$ SM was increased from 33 to $48 \%$ of the amount of chymosin added to the control SM; b) the starter/chymosin addition temperature for the $1.8 \mathrm{X}$ cheese was increased from $31^{\circ}$ to $33.5^{\circ} \mathrm{C}$ to decrease the temperature difference between the beginning and the end of cooking; c) to achieve the same milk $\mathrm{pH}$ at chymosin addition, the control SM was ripened for $45 \mathrm{~min}$, the $\mathrm{pH}$ was measured, and that $\mathrm{pH}$ was used as the target $\mathrm{pH}$ for chymosin addition to the $1.8 \mathrm{X} \mathrm{SM}$ milk; and $\mathrm{d}$ ) cooking time for the cheese making from $1.8 \mathrm{X}$ SM was reduced from 30 to $15 \mathrm{~min}$. The last three changes were designed to increase the moisture content of the $1.8 \mathrm{X}$ cheese so it would be more similar to the control. A control and a 1.8X cheese were made on the same day and this was replicated three times in three consecutive weeks.

Cheese composition, proteolysis, and hardness. Cheese samples were analyzed at four ages: $\mathrm{d} 3,30,90$, and 180, as described for trial 1.

Sensory analysis. A triangle test (Lawless and Heymann, 1999) was used to determine if there was a detectable difference in any sensory characteristic between the control and the $1.8 \mathrm{X}$ cheeses. Three pairs of control and 1.8X cheese (one pair for each of the three cheese making weeks) were evaluated by 24 untrained panelists. In each triangle test, each subject received three cheese samples to taste. Two of the cheeses were identical (same CF), while the third one was different. All possible combinations for presentation of the samples were found and randomized among the panelists. Each panelist was asked to identify the 'odd' cheese sample. All three triangle tests were performed consecutively in a single session by each of the 24 panelists. The sensory analysis was done when the cheeses made in the third week had aged for $180 \mathrm{~d}$. The cheeses were served and tasted at 8 to $10^{\circ} \mathrm{C}$ under normal lighting.

Experimental design and statistical analysis. In trial 2, cheese was made on one day from two different $\mathrm{CF}$ (1X and 1.8X) in each of 3 wk. For each week, a new batch of milk was used. A split-plot design was used for data analysis, as in trial 1 . In trial 2 , however, both the whole-plot factor (CF) and the cheese making week (i.e., batch of milk) were treated as classification variables. The transformation of age used in trial 1 was also used for trial 2 data.

For the triangle test, a probability level of 5\% $(5 \%$ chance of detecting a difference between the two cheeses when no real difference existed) was used. The power of the experiment was $90 \%$, meaning that if there was a difference perceptible to $50 \%$ of the panelists, there was $90 \%$ confidence that this difference would be detected. With the above criteria and a sample size of 24 panelists, a significant difference between the two cheeses within any one of the three triangle tests would exist if $\geq 13$ out of the 24 panelists correctly identified the 'odd' cheese sample (Lawless and Heymann, 1999).

\section{RESULTS AND DISCUSSION - TRIAL 1}

\section{Cheese Make-Times}

Make-times for trial 1 cheese making are shown in Table 2. Time from chymosin addition to beginning of whey draining decreased $(P<0.01)$ with increasing $\mathrm{CF}$. Stir-out time (i.e., time from the end of cooking to $38^{\circ} \mathrm{C}$ until whey $\mathrm{pH}$ equaled 6.40$)$ decreased $(P<0.01)$ with increasing $\mathrm{CF}$, with the $1.82 \mathrm{X}$ cheese having only $25 \%$ of the stir-out time of the control cheese. This indicates that the rate of acidification (decrease in curd $\mathrm{pH}$ ) during cheese making increased with increasing CF. The faster the rate of acidification, the higher the expected moisture loss with increasing CF.

\section{Milk and Cheese Composition}

Composition of the SM and cheeses has been reported previously (Neocleous et al., 2002). One key change in SM composition among $\mathrm{CF}$ was that serum protein concentration increased $(P<0.01)$ with increasing $\mathrm{CF}$ from $0.52 \%$ for the control SM to $0.59 \%$ for the $1.82 \mathrm{X}$ SM, indicating that there was some selective retention of milk serum proteins in the MF retentate during MF processing. There were also some key changes in cheese composition with increasing $\mathrm{CF}$ that may have impacted cheese proteolysis, functionality, and flavor development. Moisture content of the cheese decreased ( $P$ $<0.01$ ) with increasing $\mathrm{CF}$, from $35.25 \%$ for the control cheese to $33.79 \%$ for the $1.82 \mathrm{X}$ cheese. The MNFS of cheese also decreased $(P<0.01)$ with increasing $\mathrm{CF}$ from $53.80 \%$ for the control cheese to $51.84 \%$ for $1.82 \mathrm{X}$ cheese (Table 5$). \mathrm{CP}$ on a wet basis increased $(P<0.01)$ with increasing $\mathrm{CF}$, as expected, while $\mathrm{CP}$ on the dry basis did not change with increasing $\mathrm{CF}$, indicating that differences in $\mathrm{CP}$ percentage among $\mathrm{CF}$ were caused by moisture differences among the cheeses. Calcium content and calcium as a percentage of $\mathrm{CP}$ both increased significantly $(P<0.01)$ with increasing $\mathrm{CF}(\mathrm{Neo}-$ cleous et al., 2002).

The key changes in cheese composition that we observed agree to a great extent with those reported by St-Gelais et al. (1995). In our study the CN-to-fat ratio was controlled (to increase the moisture and FDB of the MF cheeses to be comparable to the control), as suggested by St-Gelais et al. (1995); however, we found (Neocleous et al., 2002) similar significant differences 
Table 5. Mean $(\mathrm{N}=4)$ cheese composition for trial 1 and mean $(\mathrm{N}=3)$ cheese composition for trial 2 for control (1X) and 1.8X cheeses.

\begin{tabular}{|c|c|c|c|c|c|}
\hline \multirow[b]{2}{*}{ Component } & \multicolumn{2}{|c|}{$\mathrm{CF}^{1}$} & \multirow{2}{*}{$\begin{array}{l}\text { Difference } \\
1.8 \mathrm{X}-1 \mathrm{X}\end{array}$} & \multirow[b]{2}{*}{ SEM } & \multirow[b]{2}{*}{ LSD } \\
\hline & $1 \mathrm{X}$ & $1.8 \mathrm{X}$ & & & \\
\hline \multicolumn{6}{|l|}{ Trial 1} \\
\hline Fat & 34.47 & 34.82 & 0.35 & 0.127 & NS \\
\hline $\mathrm{FDB}^{2}$ & 53.23 & 52.58 & -0.65 & 0.093 & NS \\
\hline Crude protein & $24.98^{\mathrm{b}}$ & $25.63^{\mathrm{a}}$ & 0.65 & 0.034 & 0.15 \\
\hline $\mathrm{PDB}^{3}$ & 38.59 & 38.71 & 0.12 & 0.038 & NS \\
\hline Moisture & $35.25^{\mathrm{a}}$ & $33.79^{\mathrm{b}}$ & -1.46 & 0.127 & 0.57 \\
\hline MNFS $^{4}$ & $53.80^{\mathrm{a}}$ & $51.84^{\mathrm{b}}$ & -1.96 & 0.094 & 0.42 \\
\hline Salt & 1.47 & 1.51 & 0.04 & 0.033 & NS \\
\hline Salt-to-moisture & 4.17 & 4.45 & 0.28 & 0.108 & NS \\
\hline Calcium & $0.775^{\mathrm{b}}$ & $0.853^{\mathrm{a}}$ & 0.078 & 0.003 & 0.01 \\
\hline Calcium, $\%$ protein $^{5}$ & $3.10^{\mathrm{b}}$ & $3.33^{\mathrm{a}}$ & 0.23 & 0.011 & 0.05 \\
\hline $\mathrm{pH}$ & 5.10 & 5.16 & 0.06 & 0.022 & NS \\
\hline \multicolumn{6}{|l|}{ Trial 2} \\
\hline Fat & 34.14 & 34.33 & 0.19 & 0.038 & NS \\
\hline FDB & 52.83 & 52.42 & -0.41 & 0.163 & NS \\
\hline Crude protein & 25.09 & 25.38 & 0.29 & 0.185 & NS \\
\hline PDB & 38.84 & 38.75 & -0.09 & 0.003 & NS \\
\hline Moisture & 35.38 & 34.50 & -0.88 & 0.258 & NS \\
\hline MNFS & 53.72 & 52.54 & -1.18 & 0.370 & NS \\
\hline Salt & 1.40 & 1.41 & 0.01 & 0.025 & NS \\
\hline Salt-to-moisture & 3.96 & 4.11 & 0.15 & 0.092 & NS \\
\hline Calcium & $0.791^{b}$ & $0.843^{\mathrm{a}}$ & 0.052 & 0.001 & 0.01 \\
\hline Calcium, \% protein & 3.15 & 3.32 & 0.17 & 0.0001 & NS \\
\hline $\mathrm{pH}$ & 5.08 & 5.16 & 0.08 & 0.017 & NS \\
\hline
\end{tabular}

\footnotetext{
${ }^{\mathrm{a}, \mathrm{b}}$ Means within the same row without a common superscript differ $(P<0.05)$. Rows with no superscripts indicate no differences $(P<0.05)$ between the means.

${ }^{1} \mathrm{CF}=$ Concentration factor.

${ }^{2} \mathrm{FDB}=$ Fat on a dry basis.

${ }^{3} \mathrm{PDB}=$ Protein on a dry basis $[(\mathrm{CP} /(100-$ moisture $)] \times 100$.

${ }^{4} \mathrm{MNFS}=$ Moisture in nonfat substance.

${ }^{5}$ Calcium $\%$ protein $=$ Calcium as a percentage of protein.
}

in the moisture between the control and MF cheeses. Significant changes in cheese moisture, MNFS, CP, total calcium content, and calcium as a percentage of $\mathrm{CP}$ with increasing $\mathrm{CF}$ may slow down proteolysis and increase cheese hardness.

\section{Titratable Acidity, $\mathrm{pH}$, and Proteolysis during Cheese Aging}

Titratable acidity and $\mathrm{pH}$. CF did not have a significant effect $(P>0.05)$ on titratable acidity of cheese during aging (Table 3 ). Titratable acidity increased ( $P$ $<0.01$ ) with age for all CF (Table 3 ). The average titratable acidity of the four cheeses was $0.50 \%$ at $d 3$ and increased linearly to an average of $0.86 \%$ at $180 \mathrm{~d}$ of age. The $1.82 \mathrm{X}$ cheese had the lowest titratable acidity throughout the aging period of $180 \mathrm{~d}$. It has been previously reported (Lau et al., 1991) that an increase in titratable acidity of Cheddar cheese with age correlates well with proteolysis during aging. No significant effects $(P>0.05)$ of $\mathrm{CF}$ or age on $\mathrm{pH}$ during cheese aging were detected (Table 3 ).
pH 4.6 soluble nitrogen. The $\mathrm{pH} 4.6$ acetate buffer SN expressed as a percentage of TN was influenced ( $P$ $<0.01)$ by $\mathrm{CF}$, age, age $\times$ age, and the interaction of $\mathrm{CF}$ and age (Table 3). All cheeses had the same amount of $\mathrm{pH} 4.6 \mathrm{SN}$ at $\mathrm{d} 3$ (Figure 1). The amount of $\mathrm{pH} 4.6 \mathrm{SN}$ increased with age for all $\mathrm{CF}$, but the increase was slower with increasing CF (Figure 1). In general, about 15 to $20 \%$ of the TN present in the cheese was soluble in $\mathrm{pH} 4.6$ acetate buffer at $180 \mathrm{~d}$ of aging. Therefore, it is unlikely that very much more than this proportion of the original casein matrix is dissolved in the water phase of the cheese. However, it is clear that some intact caseins are soluble in the water phase of cheese (Guo and Kindstedt, 1995).

12\% TCA soluble nitrogen. The 12\% TCA SN expressed as a percentage of TN was influenced by $\mathrm{CF}(P$ $<0.01)$, age $(P<0.01)$, age $\times$ age $(P<0.05)$, and the interaction of $\mathrm{CF}$ and age $(P<0.01$; Table 3$)$. All cheeses had the same amount of $12 \%$ TCA SN at d 3 (Figure 1). The amount of $12 \%$ TCA SN increased with age for all $\mathrm{CF}$, but the increase was slower with increasing $\mathrm{CF}$ (Figure 1). 


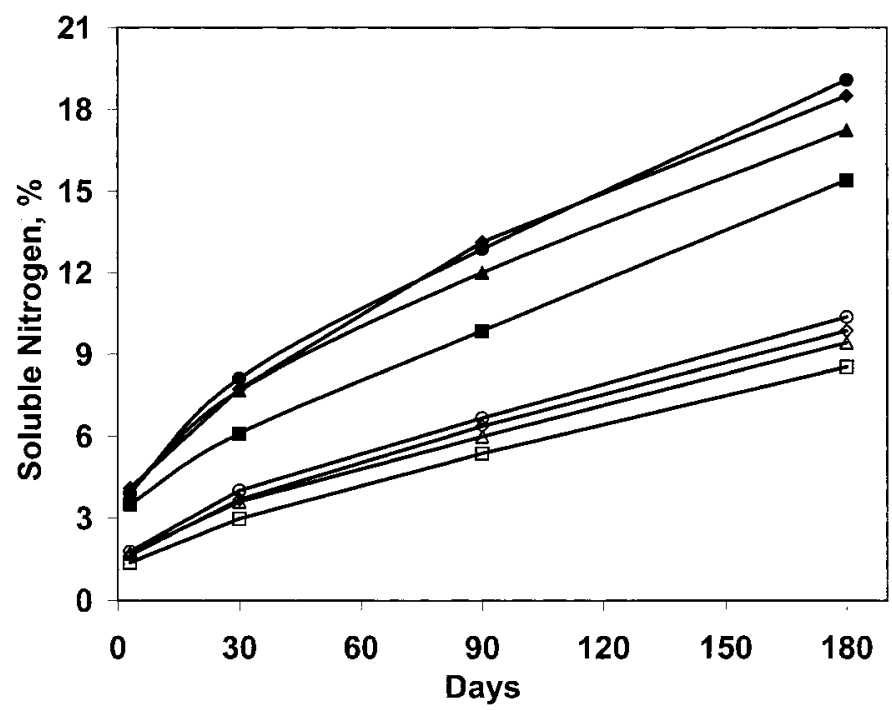

Figure 1. $\mathrm{pH} 4.6$ soluble nitrogen (SN) as a percentage of total nitrogen (TN) for 1X control cheese $(\bullet), 1.26 \mathrm{X}(\bullet), 1.51 \mathrm{X}(\boldsymbol{\Delta})$, and $1.82 \mathrm{X}(\square)$ microfiltration (MF) cheeses, and $12 \%$ TCA SN as a percentage of TN for $1 \mathrm{X}$ control cheese $(\bigcirc), 1.26 \mathrm{X}(\diamond), 1.51 \mathrm{X}(\triangle)$, and 1.82X ( $\square$ ) MF cheeses, during $180 \mathrm{~d}$ of storage at $6^{\circ} \mathrm{C}$ for trial 1.

Electrophoresis. At d 3, no significant difference $(P$ $>0.05)$ in the starting ratio of $\alpha_{\mathrm{s}}-\mathrm{CN}$ to para- $\kappa-\mathrm{CN}$ and of $\beta$-CN to para- $\kappa$-CN due to MF CF could be detected (data not shown). Degradation of $\alpha_{\mathrm{s}}-\mathrm{CN}$ was influenced $(P<0.01)$ by $\mathrm{CF}$ and age (Table 3 and Figure 2$)$, while degradation of $\beta$-CN was influenced $(P<0.05)$ by $\mathrm{CF}$ (Table 3 and Figure 3). By $30 \mathrm{~d}$ of aging, there was an obvious difference in $\alpha_{\mathrm{s}}$-CN degradation between $\mathrm{CF}$

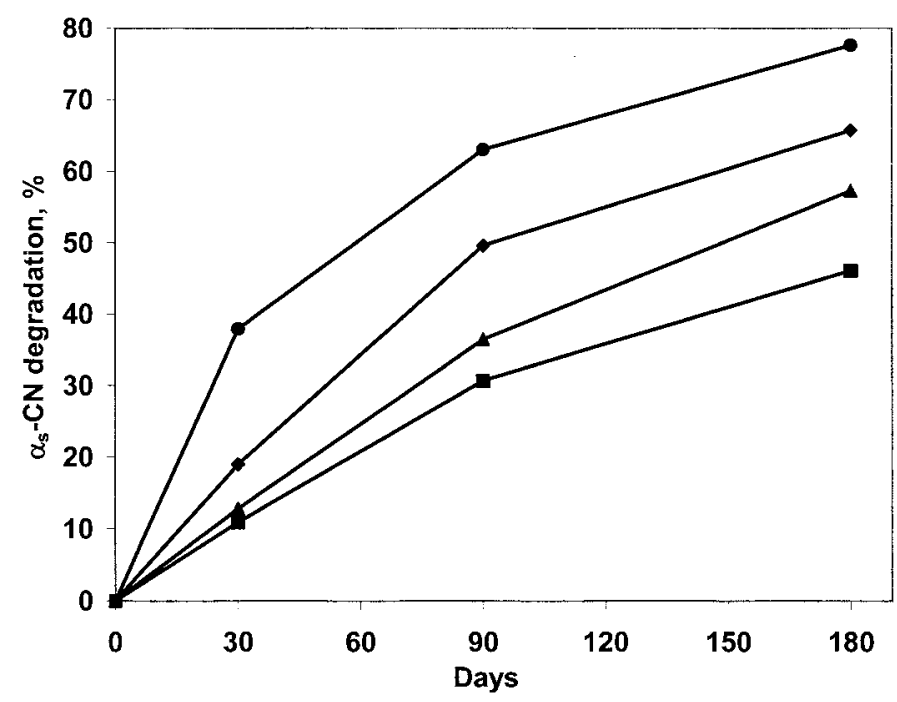

Figure 2. Percentage degradation of $\alpha_{\mathrm{s}}-\mathrm{CN}$ in $1 \mathrm{X}$ control cheese $(\bullet), 1.26 \mathrm{X}(\diamond), 1.51 \mathrm{X}(\boldsymbol{\Delta})$ and 1.82X ( $\mathbf{\square})$ microfiltration (MF) cheeses, during $180 \mathrm{~d}$ of storage at $6^{\circ} \mathrm{C}$ for trial 1 .

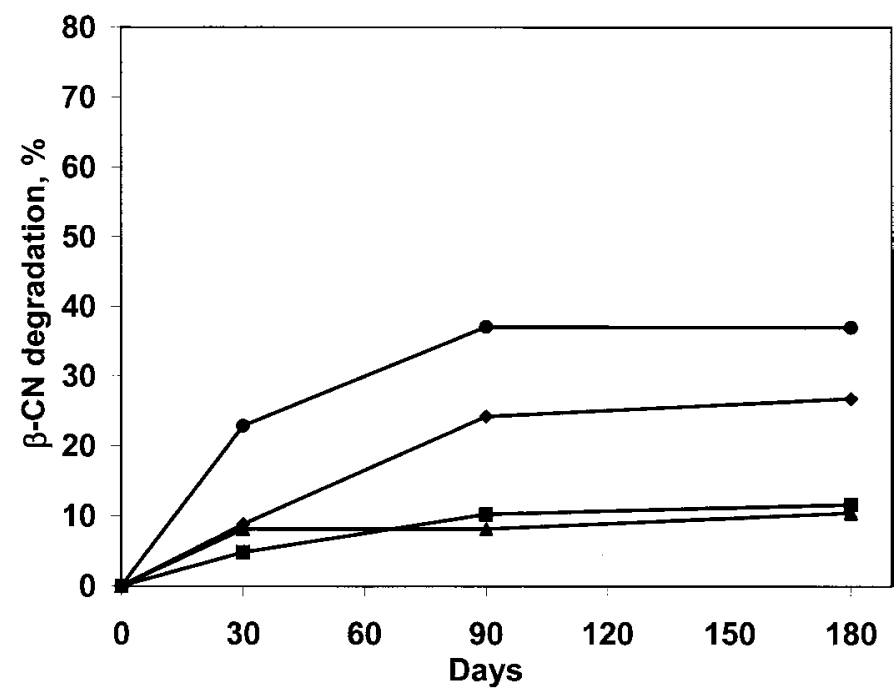

Figure 3. Percentage degradation of $\beta$-CN in 1 control cheese $(\bullet)$, $1.26 \mathrm{X}(\bullet), 1.51 \mathrm{X}(\boldsymbol{\Delta})$ and $1.82 \mathrm{X}(\mathbf{\square})$ microfiltration (MF) cheeses, during $180 \mathrm{~d}$ of storage at $6^{\circ} \mathrm{C}$ for trial 1.

(Figure 2), indicating that $\alpha_{\mathrm{s}}$-CN degradation was slower with increasing CF. This difference in degradation, developed between $\mathrm{d} 3$ and 30 and was maintained up to $180 \mathrm{~d}$ of aging (Figure 2). At $180 \mathrm{~d}$ of aging, a little more than $20 \%$ of the $\alpha_{\mathrm{s}}$-CN was left intact without at least one proteolytic cleavage. The cleavage of one peptide bond is sufficient to remove an intact casein from that band on the electrophoresis gel. The fact that $80 \%$ of the $\alpha_{\mathrm{s}}$-CN had some proteolytic damage does not mean that all the proteolysis products are in solution in the aqueous phase of the cheese.

Factors influencing proteolysis. Both external (i.e., manufacturing and ripening conditions) and internal factors (i.e., cheese composition, equilibrium of components between CN matrix and cheese water phase, and concentration of proteolytic enzymes) influence proteolysis during cheese aging. During cooling of cheese after cheese making, and during the early stages of aging (up to $8 \mathrm{~d}$ ), $\mathrm{CN}$ is released from the $\mathrm{CN}$ matrix and dissolves in the water phase of cheese (Guo and Kindstedt, 1995). The water phase of cheese contains about $4 \% \mathrm{NaCl}$, which enhances its ability to solubilize both intact caseins and some proteolysis products. A cheese with a lower MNFS has a smaller amount of water phase available to dissolve $\mathrm{CN}$, resulting in a lower percentage of the total CN being dissolved in the water phase of cheese and slower proteolysis (Lawrence and Gilles, 1980). Fox (1970) found that the state of aggregation of $\alpha_{\mathrm{s}}$ and $\beta$-caseins and their interaction with calcium had an influence on their susceptibility to proteolysis. The more aggregation of the casein and the more interaction with calcium, the less susceptible 
the proteins were to proteolysis. Assuming that proteolysis of CN may occur more easily and go to greater depth in solution in the water phase of cheese than in areas of the casein matrix with a high degree of proteinprotein interaction, less $\mathrm{CN}$ will be available to interact with the proteolytic enzymes that are also in solution in the water phase of a cheese with less MNFS. This may decrease both the extent and the rate of proteolysis during cheese aging.

Chymosin, starter peptidases, and plasmin may play a role in proteolysis of $\alpha_{\mathrm{s}}$ - and $\beta$-CN during cheese aging. Other minor enzymes (i.e., non starter bacterial enzymes, milk acid protease, phosphatases) may also play a role. Chymosin is found in the water phase of cheese (Holmes et al., 1977) and mainly contributes to the production of $\mathrm{pH} 4.6 \mathrm{SN}$ during the first $30 \mathrm{~d}$ of aging (O'Keefe et al., 1978) by degrading $\alpha_{\mathrm{s}}-\mathrm{CN}$ into medium molecular weight peptides (F. M. W. Visser and de Groot-Mostert, 1977; Barbano et al., 1993). There is also some evidence of degradation of $\beta$-CN by chymosin in cheese (F. M. W. Visser and de Groot-Mostert, 1977) and in solution (S. Visser and Slangen, 1977). This is often referred to as the primary phase of proteolysis during cheese aging (Grappin et al., 1985). Chymosin activity in cheese is decreased by higher concentrations of whey proteins (Creamer et al., 1987) dissolved in the water phase of cheese, specifically high molecular weight milk serum proteins (Lelievre et al., 1990), such as immunoglobulins (e.g., $\alpha_{2}$-macroglobulin). Akeada et al. (1971) reported that $\alpha_{2}$-macroglobulin binds to rennin $\left(\right.$ at $38^{\circ} \mathrm{C}$ ), inhibiting milk coagulation. Immunoglobulins have been reported to be concentrated in the retentate during MF of skim milk (Jost et al., 1999). Thus, when cheese is made from MF retentates, there may be a higher concentration of high molecular weight milk serum proteins retained in the water phase of cheese.

Starter peptidases, are released into the water phase of cheese during lysis of starter cells at about 30 to $60 \mathrm{~d}$ (F. M. W. Visser, 1977a). During this time, they mainly contribute to the production of $12 \%$ TCA SN (O'Keefe et al., 1978). This is often referred to as the secondary phase proteolysis during cheese aging (Rank et al., 1985). Starter peptidases degrade proteolytic products of CN produced by chymosin (Barbano et al., 1993) and, therefore, a lack of substrate will decrease their apparent activity.

Plasmin is bound to CN in milk (Politis et al., 1992) and is expected to be retained in cheese. Plasmin is released from the $\mathrm{CN}$ matrix into the water phase of cheese by addition of salt during cheese making (Grufferty and Fox, 1988). The exact contribution of plasmin to proteolysis in Cheddar cheese during aging is not clear because most studies have been done using $\mathrm{CN}$ solutions and not cheese, or carried out under $\mathrm{pH}$, ionic strength, and temperature conditions that do not exist during Cheddar cheese aging. Plasmin was reported to be responsible for $\beta$-CN proteolysis in solution (Eigel, 1977). Creamer (1975), demonstrated that there was more proteolysis caused by an enzyme that produced $\gamma$, TS, and R-caseins, in Gouda cheese than in Cheddar cheese at 3 and $14 \mathrm{wk}$ of aging. These proteolysis products are typical of those produced by the enzyme plasmin. No quantitative data were presented, but little if any degradation of $\beta$-casein and no difference was apparent in Creamer's paper for Cheddar at 3 and 14 wk of age. In contrast, the Gouda cheese showed some visible evidence of $\beta$-casein breakdown and increased presence of $\gamma$, TS, and R-caseins at $14 \mathrm{vs}$. $3 \mathrm{wk}$ of age. The Cheddar ( $\mathrm{pH}$ 4.95) and Gouda ( $\mathrm{pH}$ 5.38) cheeses were made from the same milk. Creamer stated that "the difference in $\mathrm{pH}$ may be sufficient to explain the difference in rate of $\beta$-casein degradation since the activity of milk protease is $\mathrm{pH}$ dependent." Creamer also stated that "it is possible that an enzyme from starter is breaking down $\beta$-casein, but plasmin is more likely." A study by Richardson and Pearce (1981) related the disappearance of $\beta$-CN to plasmin activity in Swiss and Cheddar cheeses. They found that Cheddar contained less plasmin than Swiss cheese and concluded that there appears to be little proteolysis in Cheddar due to plasmin. The optimum $\mathrm{pH}$ range for plasmin is $\mathrm{pH} 6.5$ to 9 , and the optimum temperature is 38 to $40^{\circ} \mathrm{C}$. These conditions are very different than those that exist Cheddar cheese during aging. Creamer (1975) also presents data for one 14- and one 30-mo-old Cheddar. However, these cheeses were not made from the same milk as the 3- and 14-wk-old cheeses presented in the same study, and there were no data on the $\mathrm{pH}$ of the 14- and 30-mo-old Cheddars. In these two cheeses there was much less intact $\beta$-casein apparent on the gel and more $\gamma$, TS, and R-caseins. It is typical for the $\mathrm{pH}$ to increase in Cheddar cheeses aged more than 12 mo. This $\mathrm{pH}$ increase may produce conditions that allow plasmin to break down $\beta$-casein. However, this may be of less practical importance because most commercial Cheddar has a pH of 5.0 to 5.2 and is consumed at ages much less than 12 mo. More studies are needed to determine if plasmin carries out proteolysis under the conditions (i.e., $\mathrm{pH}$, temperature, ionic environment) that exist in the water phase of Cheddar cheese during the first 6 mo of aging. Finally, if plasmin is active in cheese, its activity may be inhibited by changes in $\alpha_{2}$-macroglobulin concentration (Politis et al., 1992).

There are three factors that may be responsible for the observed decrease in proteolysis during aging with increasing $\mathrm{CF}$ in trial 1. First, cheese MNFS decreased $(P<0.01)$ with increasing CF (Neocleous et al., 2002). 
The lower MNFS may have caused less proteolysis because a smaller percentage of the total $\mathrm{CN}$ was accessible to proteolytic enzymes in the water phase of the cheese with increasing CF. Second, it has been reported that high molecular weight milk serum proteins (e.g., immunoglobulins) are concentrated in the MF retentate (Jost et al., 1999). In our study, concentration of serum proteins in SM increased $(P<0.01)$ with increasing $\mathrm{CF}$ (Neocleous et al., 2002), indicating a retention of these proteins with MF. The decrease in proteolysis may have been due to inhibition of chymosin activity by an increased concentration of high molecular weight milk serum proteins (e.g., $\alpha_{2}$-macroglobulin) retained in the cheese made in trial 1. A third explanation for the slower proteolysis observed with increasing $\mathrm{CF}$ in trial 1 is possibly a lower residual chymosin retained in the cheese with increasing CF. The amount of chymosin retained in Cheddar cheese is influenced by the $\mathrm{pH}$ of the curd when it is separated from the whey (Holmes et al., 1977). In the present study, curd and whey $\mathrm{pH}$ were the same for all vats at all CF in both trials 1 and 2 (Table 2) because the decision of when to drain the whey was based on a $\mathrm{pH}$ measurement during the cheese making.

It is clear from the data presented (Figures 1 to 3 ) that most of the differences in proteolysis in the cheeses made in trial 1 had developed by $30 \mathrm{~d}$ of aging, and these differences were maintained through 6 mo of aging. Thus, the major impact of $\mathrm{MF} \mathrm{CF}$ was on the primary phase of proteolysis and was most likely due to one or more of the previously mentioned factors influencing the action of chymosin during the early days of aging, either by a direct impact on the enzyme or by an indirect impact of limitation of substrate availability. In trial 2 , the cheese making conditions were changed in an attempt to eliminate factors 1 and 3 mentioned above.

\section{Hardness during Cheese Aging}

TPA hardness 1 increased $(P<0.05)$ with increasing CF (Table 3$)$ but was not influenced by age $(P>0.05)$. Similar results were obtained for hardness 2 (data not shown). At $\mathrm{d} 3$, there was a difference in hardness among fresh cheeses of the four different CF (Figure 4). This initial difference in hardness can be explained using the filled gel composite model (J. Visser, 1991). If cheese is considered a composite material, its gel consists of the CN matrix, the bound salts (calcium phosphate), and bound water, while its filler consists of the unbound water, fat, soluble $\mathrm{CN}$ and proteolysis products, whey proteins, soluble salts, and added salt. McMahon et al. (1999) found that the proportion of the total water in cheese that is tightly bound to protein

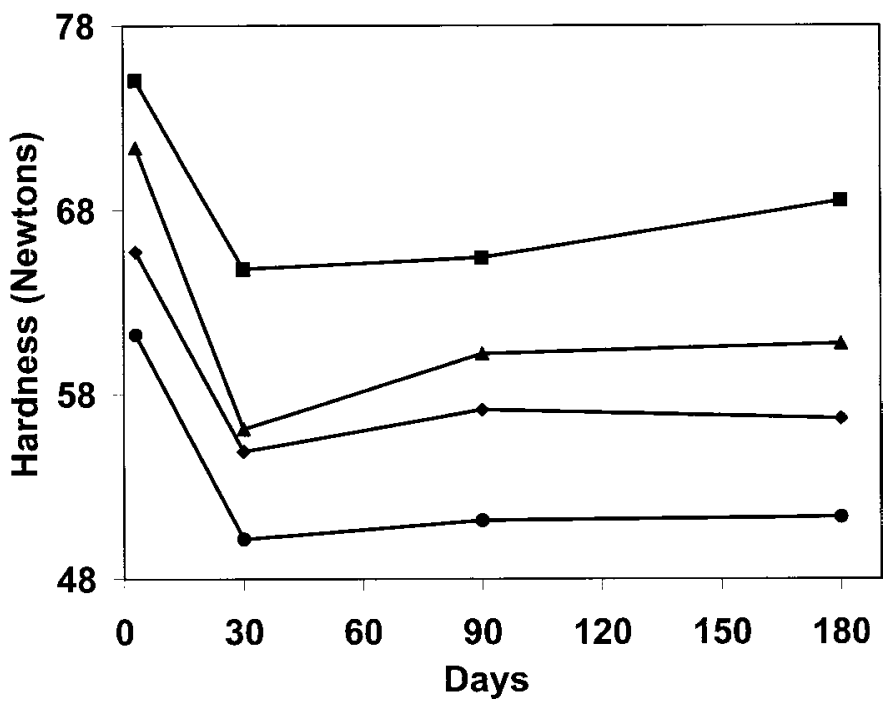

Figure 4. Hardness on first compression of $1 \mathrm{X}$ control cheese $(\bullet)$, $1.26 \mathrm{X}(\bullet), 1.51 \mathrm{X}(\mathbf{\Delta})$ and $1.82 \mathrm{X}(\mathbf{\square})$ microfiltration $(\mathrm{MF})$ cheeses, during $180 \mathrm{~d}$ of storage at $6^{\circ} \mathrm{C}$ for trial 1.

(i.e., part of the gel) did not change in Mozzarella cheese during $21 \mathrm{~d}$ of storage at $4^{\circ} \mathrm{C}$. Changing the proportion of gel to filler has an impact on cheese hardness. For example, increasing the gel and decreasing the filler volume fraction will increase hardness.

In our study, there was a decrease in moisture (decrease in the filler) and an increase in $\mathrm{CP}$ concentration and calcium as a percentage of $\mathrm{CP}$ (increase in the gel) with increasing CF (Neocleous et al., 2002), resulting in an increase in hardness of fresh (d 3) cheese with increasing CF. Creamer and Olson (1982) also demonstrated that lower moisture resulted in higher cheese hardness. During the first $30 \mathrm{~d}$ of aging, all four cheeses had a large reduction in hardness (Figure 4). Creamer and Olson (1982) also report a similar reduction in Cheddar cheese hardness during the first $30 \mathrm{~d}$ of aging followed by no change in hardness from 10 to $109 \mathrm{wk}$ of aging. Creamer and Olson (1982) indicated, based on their results, that if the $\alpha_{\mathrm{s} 1}-\mathrm{CN}$ molecule is cleaved so that it loses its ability to act as a link in the protein network, then the network would lose its strength, and they proposed that cleavage of a few peptide bonds can cause a relatively large change in the hardness of young Cheddar cheese. No quantitative electrophoresis data were presented by Creamer and Olson. In the present study (Figures 2 and 6), the loss of intact $\alpha_{\mathrm{s} 1}$-CN more than doubles from d 30 to 90 with no change in cheese hardness. Thus, another potential explanation of why hardness decreases during the first $30 \mathrm{~d}$ and then remains constant is as follows: During the first $30 \mathrm{~d}$ of cheese aging, $\mathrm{CN}$ solubilizes from the $\mathrm{CN}$ matrix (gel) into the water phase (filler) of the cheese (Guo and 
Kindstedt, 1995). This migration decreases the gel volume and increases the filler volume, resulting in a decrease in hardness. From d 0 to 30, about 30 to $40 \%$ of the intact $\alpha_{\mathrm{s}}-\mathrm{CN}$ was degraded (Figures 2 and 6), while an additional $40 \%$ was degraded after $30 \mathrm{~d}$. The fact that this additional amount of degradation of intact CN (Figures 2 and 6) did not produce any decrease in hardness (Figures 4 and 7) would suggest that there could be other important factors influencing cheese hardness. Our results agree with the results of St-Gelais et al. (1995) who also observed that cheese hardness was significantly higher in the MF cheeses compared to the control cheese, and the difference was maintained from 6 to 12 wk of aging.

\section{Cheese Flavor}

The flavor of the cheeses in trial 1 was evaluated informally by several people. The overall flavor of all cheeses produced in trial 1 was good and typical of Cheddar cheese. However, the flavor intensity decreased with increasing CF. This observation was consistent with the difference in moisture content and reduced proteolysis as CF increased. Instead of conducting a formal sensory evaluation of the trial 1 cheeses, it was decided that it would be more productive to conduct a second cheese making trial where modifications of the cheese making procedure would be made to achieve more similar composition and proteolysis between the control cheese and the cheese made from 1.8X MF retentate.

\section{RESULTS AND DISCUSSION - TRIAL 2}

\section{Cheese Make-Times}

Make-times for trial 2 cheese making are shown in Table 4. The modifications in the cheese making procedure eliminated the difference in stir-out time between the control and the $1.82 \mathrm{X}$ cheese that were observed in trial 1 (Table 2). Both control and $1.8 \mathrm{X}$ cheese makings had similar stir-out times of about $32 \mathrm{~min}$ in trial 2 (Table 4$)$. In trial 2 , the total make-time was longer $(P$ $<0.05$ ) for the 1.8X cheese making than the control due to a decreased total rate of acidification by the starter.

\section{Milk and Cheese Composition}

In trial 2, SM composition (data not shown) was similar to trial 1 (Neocleous et al., 2002). A comparison of the cheese composition of the control (1X) cheese and the cheese of the highest CF (1.8X) for trials 1 and 2 is shown in Table 5. In trial 2, composition of the $1.8 \mathrm{X}$ cheese was more similar to the composition of the control cheese than in trial 1 (Table 5). First, the significant difference in moisture content and MNFS between the two cheeses in trial 1 was not detected in trial 2 . The reduction in the cooking time, the decrease in the temperature gradient from the beginning to the end of cooking in the $1.8 \mathrm{X}$ cheese making in trial 2 and finally, the increase in stir-out time and the decrease in the acidification rate successfully resulted in moisture, MNFS, CP, and calcium as a percentage of CP for the $1.8 \mathrm{X}$ cheese that were not significantly different from the control cheese. Calcium content on a wet basis, however, was still significantly higher in the $1.8 \mathrm{X}$ cheese than in the control cheese, as in trial 1 (Table 5).

\section{Titratable Acidity, $\mathrm{pH}$, and Proteolysis during Cheese Aging}

Titratable acidity did not change $(P>0.05)$ with $\mathrm{CF}$ but increased significantly with age $(P<0.01)$ for both $\mathrm{CF}$ (Table 6). The average titratable acidity of the control plus the $1.8 \mathrm{X}$ cheeses was $0.55 \%$ at $\mathrm{d} 3$ and increased linearly to an average of $0.94 \%$ at $180 \mathrm{~d}$ of age (similar to trial 1). There was no significant effect $(P>$ 0.05) of $\mathrm{CF}$ on cheese $\mathrm{pH}$ in trial 2 (Table 6). Cheese $\mathrm{pH}$, however, was significantly influenced by age $(P<$ $0.01)$ and age $\times$ age $(P<0.05$; Table 6$)$. The average $\mathrm{pH}$ of the control plus the $1.8 \mathrm{X}$ cheeses was 5.12 at $\mathrm{d} 3$ and increased to an average of 5.15 at $180 \mathrm{~d}$ of aging.

There was no significant $\mathrm{CF}$ effect $(P>0.05)$ on $\mathrm{pH}$ 4.6 SN (Table 6 and Figure 5), but there was a significant age and age $\times$ age effect $(P<0.01)$. Thus, the changes in cheese making procedure (Table 1) eliminated the significant differences in $\mathrm{pH} 4.6 \mathrm{SN}$ observed in trial 1 (Table 3 and Figure 1). There was a significant effect of CF on $12 \%$ TCA SN because the interaction of $\mathrm{CF}$ and age was significant $(P<0.01$; Table 6$)$. However, the magnitude of the difference in $12 \%$ TCA SN between the control and the $1.8 \mathrm{X}$ cheese in trial 2 (Figure 5) was smaller than in trial 1 (Figure 1). In trial 2, the SDS PAGE separation of caseins had better resolution than in trial 1, with complete separation of $\alpha_{\mathrm{s} 1}, \alpha_{\mathrm{s} 2}$, and $\beta$ CN. No significant effect $(P>0.05)$ of $\mathrm{CF}$ on degradation of $\alpha_{\mathrm{s} 1}-\mathrm{CN}, \alpha_{\mathrm{s} 2}-\mathrm{CN}$, (Table 6 and Figure 6) and $\beta-\mathrm{CN}$ (data not shown) was detected in trial 2. In trial 2, no difference in degradation of $\alpha_{\mathrm{s} 1}$ or $\alpha_{\mathrm{s} 2}$-casein was detected among the $1 \mathrm{X}$ and $1.8 \mathrm{X}$ treatments at $\mathrm{d} 30$ or later in aging. This confirms that differences in the primary phase of proteolysis that were observed in trial 1 (Figure 2) were eliminated by the changes in cheese making procedure used in trial 2 (Figure 6). Very little degradation $\beta$-CN for either treatment was observed in trial 2. No significant effects of $\mathrm{CF}$, or time of aging, or their interaction on degradation of $\beta$ - $\mathrm{CN}$ were observed. 
Table 6. Degrees of freedom, mean squares, probabilities (in parenthesis), and $\mathrm{R}^{2}$ for titratable acidity, $\mathrm{pH}$, hardness on first compression, and $\mathrm{pH} 4.6$ and $12 \%$ TCA soluble nitrogen (SN) of Cheddar cheese during $180 \mathrm{~d}$ of storage at $6^{\circ} \mathrm{C}$ for trial 2.

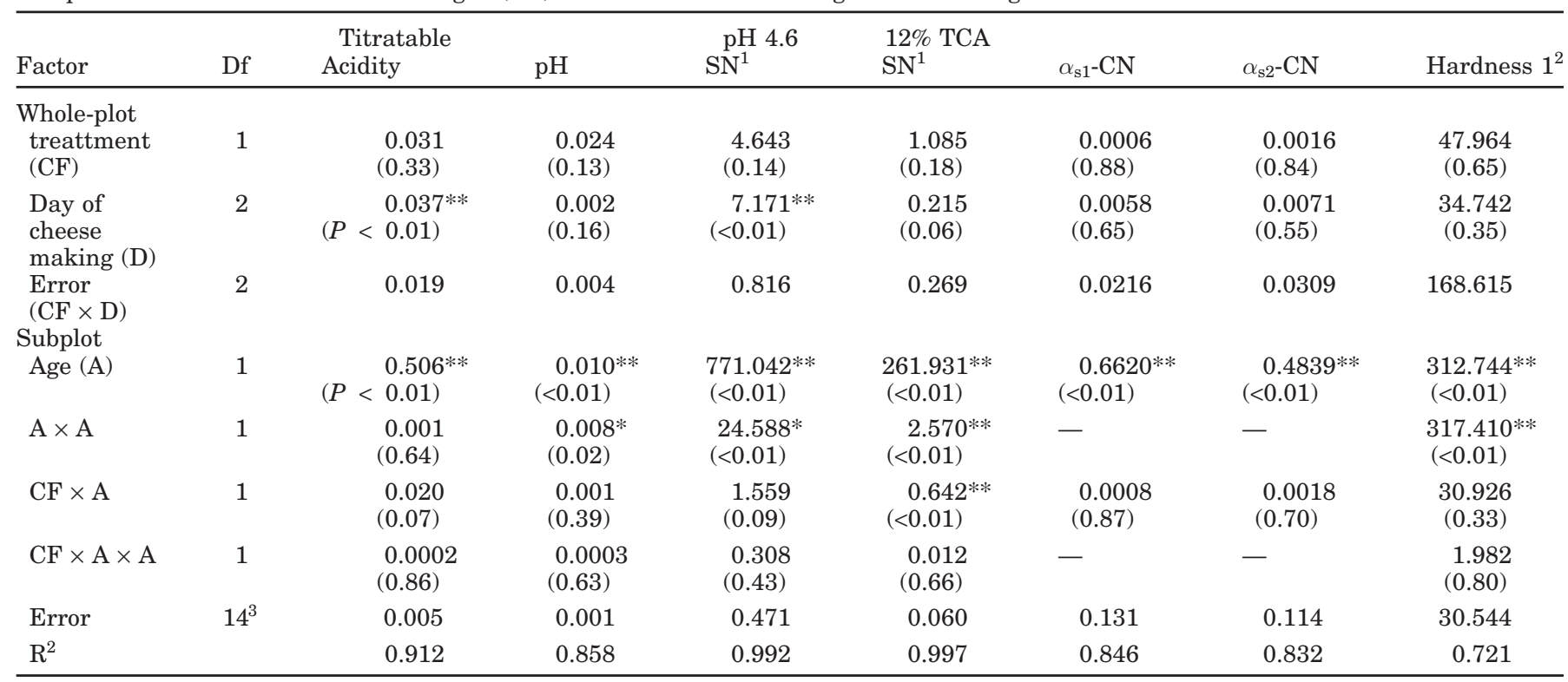

${ }^{1} \mathrm{SN}=$ Soluble nitrogen.

${ }^{2}$ Hardness on first compression.

${ }^{3}$ Degrees of freedom for the error term of $\alpha_{\mathrm{s} 1}$ and $\alpha_{\mathrm{s} 2} \mathrm{CN}$ breakdown $=10$.

$* 0.01 P \leq 0.05$

$* * P \leq 0.01$.

\section{Cheese Hardness and Flavor during Cheese Aging}

No $\mathrm{CF}$ effect $(P>0.05)$ on hardness 1 was detected during cheese aging in trial 2 (Table 6). A significant

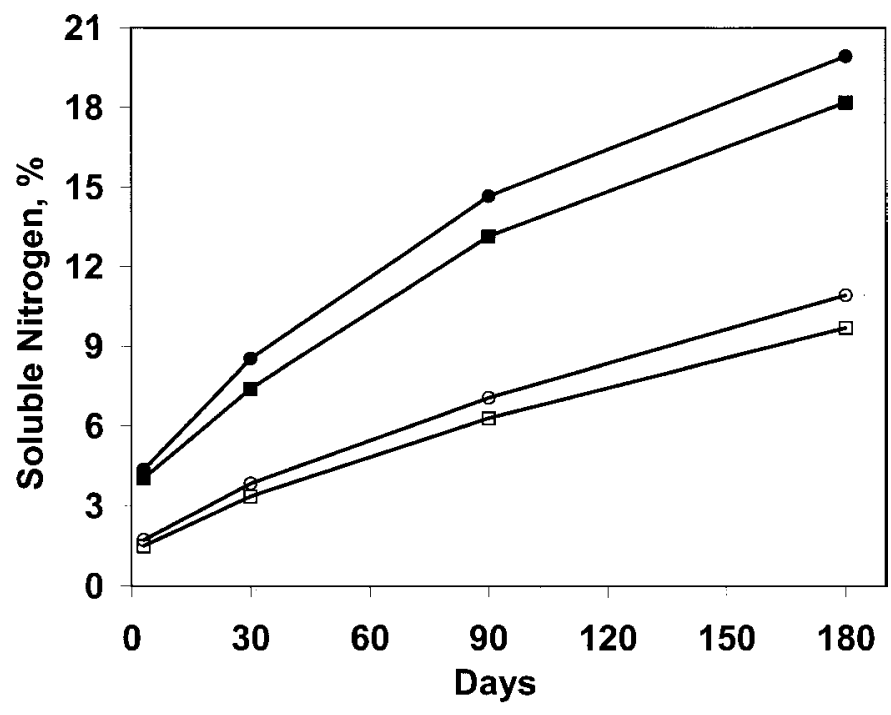

Figure 5. $\mathrm{pH} 4.6$ soluble nitrogen $(\mathrm{SN})$ as a percentage of total nitrogen (TN) for $1 \mathrm{X}$ control cheese $(\mathbf{)})$ and $1.8 \mathrm{X}$ microfiltration $(\mathrm{MF})$ cheese (ם), and $12 \%$ TCA SN as a percentage of TN for $1 \mathrm{X}$ control cheese $(\bigcirc)$ and $1.8 \mathrm{X}$ MF cheese $(\square)$, during $180 \mathrm{~d}$ of storage at $6^{\circ} \mathrm{C}$ for trial 2 .
$(P<0.01)$ age effect was detected, with hardness decreasing from $\mathrm{d} 3$ to 30 but remaining relatively constant from d 30 to 180 , as in trial 1 (Figure 7).

In all three triangle tests for the three different pairs of cheeses, less than 13 of the 24 panelists correctly identified the 'odd' cheese sample. Thus, at the $P=$

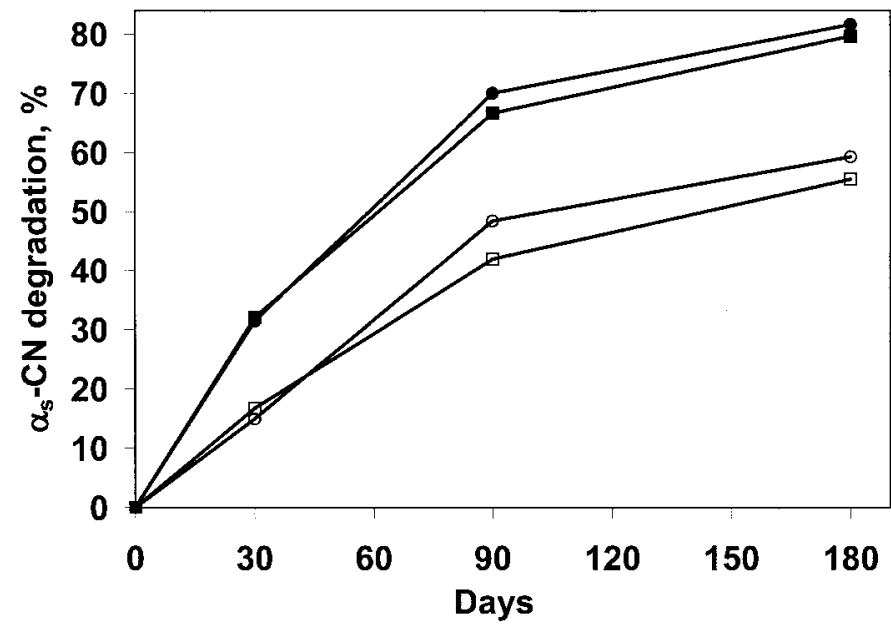

Figure 6. Percentage degradation of $\alpha_{\mathrm{s} 1}-\mathrm{CN}$ in $1 \mathrm{X}$ control cheese ([) and 1.8X ( microfiltration (MF) cheese, and percentage degradation of $\alpha_{\mathrm{s} 2}-\mathrm{CN}$ in $1 \mathrm{X}$ control cheese $(\bigcirc)$ and 1.8X $(\square)$ microfiltration (MF) cheese, during $180 \mathrm{~d}$ of storage at $6^{\circ} \mathrm{C}$ for trial 2. 


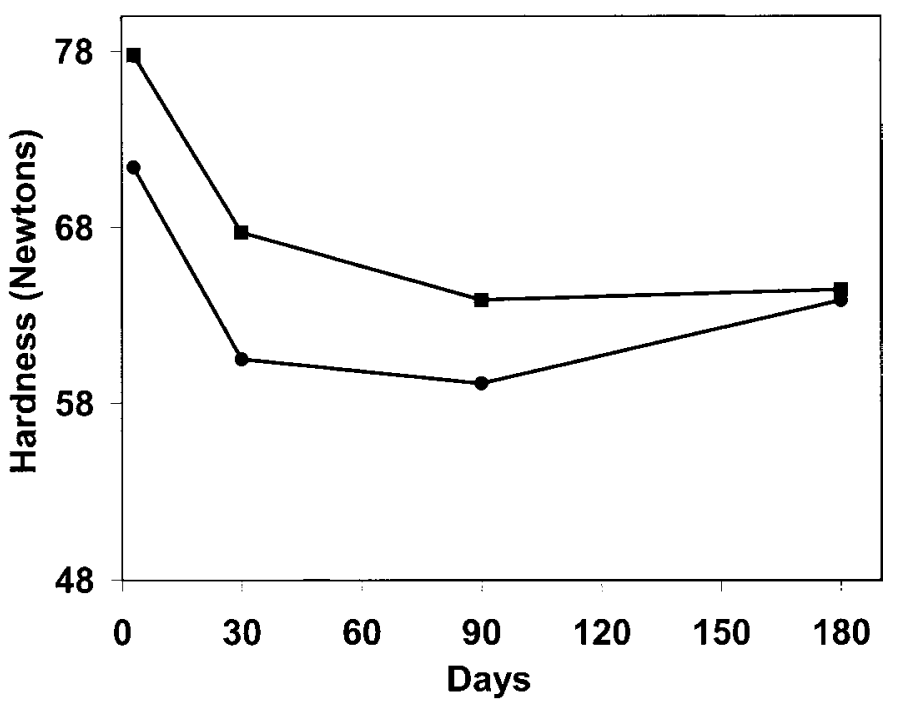

Figure 7. Hardness on first compression of $1 \mathrm{X}$ control cheese ([) and 1.8X microfiltration (MF) cheese ( $\mathbf{\square})$, during $180 \mathrm{~d}$ of storage at $6^{\circ} \mathrm{C}$ for trial 2 .

0.05 , no significant difference in sensory characteristics between the control and the $1.8 \mathrm{X}$ cheese could be detected in trial 2.

\section{Elimination of Differences Due to MF CF}

Why were most of the differences in proteolysis eliminated in trial 2 ? As indicated in the results and discussion for trial 1 , there were three factors that may have been responsible for the effect of MF CF on proteolysis, hardness, and flavor in trial 1. Two of these factors (1 and 3) were eliminated by the changes in the cheese making procedure used in trial 2. Any inhibition of chymosin by retained high molecular weight serum proteins should be the same in both trials. There should also be the same amount of plasmin in the milk for both trials.

Moisture (and MNFS) difference between the control and the $1.8 \mathrm{X}$ cheese was eliminated in trial 2 (Table 5 ), providing similar total $\mathrm{CN}$ in solution in the water phase and allowing similar CN accessibility as a substrate to the proteolytic enzymes in the water phase of the cheese. More chymosin was added to the 1.8X SM in trial 2, and more chymosin was expected to be retained in the water phase of the $1.8 \mathrm{X}$ cheese, resulting in proteolysis in the $1.8 \mathrm{X}$ cheese that was not different from the control cheese.

Why was the difference in hardness due to CF eliminated in trial 2? Moisture, CP, and calcium as a percentage of $\mathrm{CP}$ were not significantly different for control and $1.8 \mathrm{X}$ cheese in trial 2 (Table 5), resulting in the same gel and filler volume for the two cheeses and, therefore, the same initial hardness. There was a reduction in hardness during the first $30 \mathrm{~d}$ of aging (similar to trial 1) for both control and 1.8X cheeses (Figure 7) due to protein solubilization into the water phase of the cheese (Guo and Kindstedt, 1995) that reduced the gel volume and increased the filler volume, as in trial 1. Hardness changes from d 30 to 180 were small compared to changes in the first $30 \mathrm{~d}$ (Figure 7). This may be because the proteolytic and peptidase enzymes are breaking down $\mathrm{CN}$ that are already in solution in the water phase of the cheese (i.e., filler) and, therefore, proteolysis of these proteins has little effect on hardness.

No difference in the sensory characteristics between control and 1.8X MF cheese was detected in trial 2. Thus, increasing chymosin and making the composition (moisture) of the two cheeses more similar allows production of aged Cheddar cheese, from up to $1.8 \mathrm{X} \mathrm{MF}$ retentate, that will not be perceived as different from aged Cheddar cheese produced without MF.

\section{CONCLUSIONS}

The rate of proteolysis decreased with increasing MF $\mathrm{CF}$ in trial 1, the major impact of MF CF being on primary phase of proteolysis. Three factors might have been responsible for slowing of proteolysis: limitation of substrate $(\mathrm{CN})$ availability for chymosin due to low MNFS, inhibition of chymosin activity by high molecular weight milk serum proteins retained in the MF retentate, or low residual chymosin retained in the cheese with increasing CF. Hardness of fresh cheese increased with increasing $\mathrm{CF}$ (trial 1). A decrease in moisture (i.e., decrease in filler volume fraction) and an increase in $\mathrm{CP}$ concentration and calcium as a percentage of $\mathrm{CP}$ (i.e., increase in gel volume fraction) with increasing $\mathrm{CF}$, increased hardness of fresh (d 3) cheese. A large reduction in hardness in all trial 1 cheeses during the first $30 \mathrm{~d}$ of aging was observed, with no further change from d 30 to 180, when proteolysis still occurs. Finally, cheese flavor intensity decreased with increasing $\mathrm{CF}$ in trial 1.

Most of the differences in proteolysis were eliminated in trial 2 by changes in the cheese making procedure that increased MNFS in the $1.8 \mathrm{X}$ cheese and by adding more chymosin to the $1.8 \mathrm{X} \mathrm{SM}$ with the goal of retaining more chymosin in the $1.8 \mathrm{X}$ cheese. The difference in cheese hardness due to $\mathrm{CF}$ observed in trial 1 was eliminated in trial 2 . Cheese hardness during aging changed similarly in both trials 1 and 2 . In general, cheese hardness decreased substantially in the first $30 \mathrm{~d}$ and was relatively stable from $d 30$ to 180 . We hypothesize that solubilization of $\mathrm{CN}$ from the $\mathrm{CN}$ matrix to the water phase of the cheese could be responsible for the initial 
decrease in hardness. It is possible that, after protein solubilization during the first $30 \mathrm{~d}$ of aging, proteolytic enzymes were further breaking down intact $\mathrm{CN}$ that were already in solution in the water phase of the cheese without influencing cheese hardness. Finally, no difference in the sensory characteristics between the control and the $1.8 \mathrm{X}$ cheese was detected in trial 2 . The increase in moisture and increase in chymosin retained in the cheese were able to overcome any inhibitory effect of increased $\alpha_{2}$-macroglobulin concentration in cheese. Therefore, increasing chymosin and adjusting the cheese making time to make the composition of the two cheeses more similar allows production of aged Cheddar cheese from milk concentrated up to $1.8 \mathrm{X}$ by $\mathrm{MF}$ that will not be perceived as different from aged Cheddar cheese produced without MF.

\section{ACKNOWLEDGMENTS}

The authors thank Joanna Lynch, Maureen Chapman, Laura Landolf, Pat Wood, Bob Kaltaler, and Paula Benitez for technical support and the Northeast Dairy Foods Research Center and Dairy Management, Inc. (Rosemont, IL); the America-Mideast (AMIDEAST) Educational and Training Services, Inc. (Washington, DC); and the Hochstrasser Endowment for financial support.

\section{REFERENCES}

Akeada, H., H. Miura, and M. Mikami. 1971. Studies on the rennin inhibitor in serum. Part II. Inhibiting action on rennin coagulation by $\alpha_{2}$-macroglobulin. J. Agric. Chem. Soc. Japan. 45:449-453.

Barbano D. M., K. Y. Chu, J. J. Yun, and P. S. Kindstedt. 1993. Contributions of coagulant, starter, and milk enzymes to proteolysis and browning in Mozzarella cheese. Pages 65-79 in Proc. 30th Annual Marshall Italian Cheese Seminar, Madison, WI.

Bourne, M. C. 1978. Texture Profile Analysis. Food Technol. 32:62-66.

Bynum, D. G., and D. M. Barbano. 1985. Whole milk reverse osmosis retentates for Cheddar cheese manufacture: chemical changes during aging. J. Dairy Sci. 68:1-10.

Creamer, L. K. 1975. $\beta$-casein degradation in Gouda and Cheddar cheese. J. Dairy Sci. 58:287-292.

Creamer, L. K., M. Iyer, and J. Lelievre. 1987. Effect of various levels of rennet addition on characteristics of Cheddar cheese made from ultrafiltered milk. N.Z. J. Dairy Sci. Technol. 22:205-214.

Creamer, L. K., and N. F. Olson. 1982. Rheological evaluation of maturing Cheddar cheese. J. Food Sci. 47:631-646.

Eigel, W. N. 1977. Formation of $\gamma_{1}-\mathrm{A}^{2}, \gamma_{2}-\mathrm{A}^{2}$, and $\gamma_{3}$-A caseins by in vitro proteolysis of $\beta$-casein $\mathrm{A}^{2}$ with bovine plasmin. Int. J. Biochem. 8:187-192.

Fox, P. F. 1970. Influence of aggregation on the susceptibility of casein to proteolysis. J. Dairy Res. 37:173-179.

Garrett, N. L. T. 1987. Continuous production of Cheddar cheese according to the Sirocurd method. Eur. Food Dairy J. 53 (5):135-143.

Grappin, R., T. C. Rank, and N. F. Olson. 1985. Primary proteolysis of cheese proteins during ripening-A review. J. Dairy Sci. 68:531-540.
Green, M. L., F. A. Glover, E. M. W. Scurlock, R. J. Marshall, and D. S. Hatfield. 1981. Effect of use of milk concentrated by ultrafiltration on the manufacture and ripening of Cheddar cheese. J. Dairy Res. 48:333-341.

Grufferty, M. B., and P. F. Fox. 1988. Factors affecting the release of plasmin activity from casein micelles. N.Z. J. Dairy Sci. Technol. 23:153-163.

Guo, M. R., and P. S. Kindstedt. 1995. Age-related changes in the water phase of Mozzarella cheese. J. Dairy. Sci. 78:2099-2107.

Holmes, D. G., J. W. Duersch, and C. A. Ernstrom. 1977. Distribution of milk clotting enzymes between curd and whey and their survival during Cheddar cheese making. J. Dairy Sci. 60(6):862-869.

Jost, R., R. Brandsma, and S. Rizvi. 1999. Protein composition of micellar casein obtained by cross-flow microfiltration of skimmed milk. Int. Dairy J. 9:389-390.

Lau, K. Y., D. M. Barbano, and R. R. Rasmussen. 1991. Influence of pasteurization of milk on protein breakdown in Cheddar cheese during aging. J. Dairy Sci. 74:727-740.

Lawless, H., and H. Heymann. 1999. Sensory Evaluation of FoodPrinciples and Practices. Aspen Publishers, Inc., Gaithersburg, MD.

Lawrence, R. C., and J. Gilles. 1980. The assessment of the potential quality of young Cheddar cheese. N.Z. J. Dairy Sci. Technol. 15:1-12.

Lelievre, J., L. K. Creamer, and K. L. Tate. 1990. Inhibition of calf vell and microbial rennet action by whey protein concentrate. Milchwissenschaft. 45:2:71-75.

McMahon, D. J., R. L. Fife, and C. J. Oberg. 1999. Water partitioning in Mozzarella cheese and its relationship to cheese meltability. J. Dairy Sci. 82:1361-1369.

Nath, K. R., and R. A. Ledford, 1973. Growth response of Lactobacillus casei variety casei to proteolysis in cheese during ripening. J. Dairy Sci. 56:710-715.

Neocleous, M., D. M. Barbano, and M. A. Rudan. 2002. Impact of low concentration factor microfiltration on milk component recovery and Cheddar cheese yield. J. Dairy Sci. 85:2415-2424.

O'Keefe, A. M., P. F. Fox, and C. Daly. 1978. Proteolysis in Cheddar cheese: role of coagulant and starter bacteria. J. Dairy Res. 45:465-477.

Politis, I., D. M. Barbano, and R. C. Gorewit. 1992. Distribution of plasminogen and plasmin in fractions of bovine milk. J. Dairy Sci. 75:1402-1410.

Rank, T. C., R. Grappin, and N. F. Olson. 1985. Secondary proteolysis of cheese during ripening: a review. J. Dairy Sci. 68:801-805.

Richardson, B. C., and N. K. Pearce. 1981. The determination of plasmin in dairy products. N.Z. J. Dairy Technol. 16:209.

SAS User's Guide: Statistics, Version 6 Edition. 1990. SAS Inst., Inc., Cary, NC.

St-Gelais, D., M. Piette, and G. Belanger. 1995. Production of cheddar cheese using milk enriched with microfiltered milk retentate. Milchwissenschaft. 50 (11):614-618.

Swientek, R. J. 1984. Continuous cheese making process utilizes ultrafiltration technology. Food Proc., 45 (12):103-106.

Verdi, R. J., D. M. Barbano, and M. E. Dellavalle. 1987. Variability in true protein, $\mathrm{CN}$, nonprotein nitrogen, and proteolysis in high and low somatic cell milks. J. Dairy Sci. 70:230-242.

Visser, F. M. W. 1977a. Contribution of enzymes from rennet, starter bacteria and milk to proteolysis and flavor development in Gouda cheese. 1. Description of cheese and aseptic cheese making techniques. Neth. Milk Dairy J. 31:120-133.

Visser, J. 1991. Factors affecting the rheological and fracture properties of hard and semi-hard cheeses. Bull. Int. Dairy Fed. 268:49, Int. Dairy Fed., Brussels, Belgium.

Visser, F. M. W., and A. E. A. de Groot-Mostert. 1977. Contribution of enzymes from rennet, starter bacteria and milk to proteolysis and flavor development in Gouda cheese. 4. Protein breakdown: a gel electrophoretical study. Neth. Milk Dairy J. 31:247-264.

Visser, S., and K. J. Slangen, 1977. On the specificity of chymosin (rennin) in its action on bovine $\beta$-CN. Neth. Milk Dairy J. 31:16-30. 